\title{
Economic viability of private sector participation in management of municipal solid waste in Makurdi metropolis of Nigeria
}

\author{
Kwadzah Telumun Kenneth ${ }^{1}$, Enokela, Onum Shadrach ${ }^{1}$, Johnson Abinbola Otun ${ }^{2}$ \\ ${ }^{1}$ Department of Agricultural and Environmental Engineering, Federal University of Agriculture, Makurdi, Nigeria \\ ${ }^{2}$ Department of Water resources and Environmental Engineering, Ahmodu Bello University, Zaria-Nigeria
}

Email address:

enokladish@yahoo.com(Enokela, Onum Shadrach)

To cite this article:

Kwadzah Telumun Kenneth, Enokela, Onum Shadrach, Johnson Abinbola Otun. Economic Viability of Private Sector Participation in Management of Municipal Solid Waste in Makurdi Metropolis of Nigeria. International Journal of Environmental Monitoring and Analysis. Vol. 1, No. 4, 2013, pp. 147-153. doi: 10.11648/j.ijema.20130104.16

\begin{abstract}
Assessment of the economic viability of private sector participation in solid waste management within Makurdi metropolis was carried out. Three hundred questionnaires were administered to the resident waste generators and five hundred to the waste management collectors (service -providers). A survey of equipment and machinery required for proficient waste management services by government and private sector were also conducted with comprehensive inventories created. With a loan of $\$ 452,210.94$ collected by any waste management company in Makurdi metropolis from commercial banks/institutions, the analysis revealed that, the company should be able to realize $\$ 4,794,352.50 /$ annum with a servicing loan of $\$ 94,964.30 /$ annum which gave a Net cash at hand of $\$ 4,247,177.26 /$ annum. Three more numeric models were used to analyses the viability of the business for a period of one year for each of the models, i.e.; the net present value (NPV) model, the profitability index (P.I) model and the return on investment (ROI) model. The models yielded the following results respectively; $\$ 2,802,331: 00,6.2,9.4$, which indicates that, private sector participation in solid waste management in Makurdi metropolis, is lucrative and recommended for implementation.
\end{abstract}

Keywords: Solid Waste, Management, Assessment, Economic Viability, Private Sector, Makurdi Metropolis

\section{Introduction}

Waste according to [1] is technically defined as any material unused and rejected as worthless or unwanted. Waste from residential places according to World Bank [2] is comprised of food waste, paper, cardboard, plastics, textiles, leather, yard wastes, wood, glass, metals, ashes, special wastes (e.g. bulky items, consumer electronics, white goods, batteries, oil, tires), and households hazardous wastes. Waste generation rates are affected by socioeconomic development, degree of industrialization, and climate. Generally, the greater the economic prosperity and the higher the percentage of urban population, the greater the amount of solid waste produced [3].

Solid waste management (SWM) is an integral part of the urban environment and planning of the urban infrastructure to ensure a safe and healthy human environment while considering the promotion of sustainable economic growth. Rapid economic growth by industrialization of the developing countries has created serious problems of waste disposal due to uncontrolled and unmonitored urbanization [4]. The problem is further aggravated by the lack of financial as well human resources trained in SWM practices in the sphere of collection, transportation, processing and final disposal [5]. Whereas aspects like recycle, reuse and recovery of the solid waste is grossly demand and supply driven or disorganized in most cases. In this scenario, the responsible persons or agencies concerned with the public health and environment protection face the crisis of ineffective MSWM. The waste generated in the developing countries is similar in composition, the variation between regions being dictated by the climatic, cultural, and industrial, infrastructural and legal factors [6]. Waste management is carried out to recover resources from it.

The concept of "Poor Solid Waste Management (SWM)" is a challenge throughout the world in both developed and developing countries. People always generate solid waste through their daily activities. These solid wastes require proper management so as to minimize the risk imposed on 
the dwellers and the surrounding environment. [7] Reveals that, in developed countries such as United States, over $72 \%$ of their Waste goes into the ground in landfills, about $15 \%$ is burned and only $13 \%$ is recycled or reused.

In Makurdi metropolis, burning of the solid waste is the commonest method of disposal adapted by her residents and the waste management service providers. This method of disposal can be harmful to the surrounding dwellers as it infects the air around with toxic substances (gases) and other micro organisms in the soil. Some of the residents deposit their garbage by the road sides, undeveloped plots, uncompleted buildings, drains (gutters) and riversides (river banks). These trash are gotten rid of by the state government sanitation agents, since no one can accept to pay the bills of collecting them.

This nonchalant attitude of the residents in respect to waste disposal calls for adequate education and orientation as it exposes the dwellers to harmful infections caused by vectors (flies, maggots, etc) and reptiles (snakes). They also serve as hideouts for evil acts, which jeopardize the residents. [8].

According to [9], the education or awareness on the importance of enforcing waste management can be created through means such as; Continuous training of manpower (students or social groups) that could extend the awareness to dwellers, campaign rallies using placards and public address systems e.t.c.

Waste, broadly speaking can either be solid or liquid. For the purpose of this study, only the solid waste generated was considered. The study was also focused on the urban areas of Makurdi which covers; Wurukum, High Level, Wadata and Modern Market, The category of areas include; residential houses, small and large scale business premises, and industries.

In Makurdi metropolis, about 49,000tons/annum of waste was generated in 2003 [9], similarly, [10] estimated waste generation of 66,560 tons/annum in 2002. As a metropolitan area, the rate at which waste is generated within Makurdi metropolis requires an extensive waste management process that can cater for the good health of its populace. Makurdi urban center and its environs experiences untidy surroundings due to inadequate sanitary services as rendered by the state government. This ugly situation made government to involve the private sector in the waste management process. Such private persons could be companies and individuals operating independently.

In 2005, the Benue State government licensed five (5) private companies to carry out the services within the metropolis. These companies were viz: Danihopewell Services Ltd, Dovy Associates, Joab Services, Tsefan Ventures Ltd and Living in the environment, all with head offices located in Makurdi (The study area). However, due to the poor turn-up of residents in this regard, most of these companies suffered relegation as they could not cater for their labour-force, hence shut down. Presently, only Danihopewell Services Ltd is still striving to stand. Their services include moving from one establishment (Banks,
Industries etc.) to another with collection Vans to empty the bins and/or wheelies put within the premises for daily waste collection. The five license private sector collectors were given reference list of inventory as presented in the table below. By implication each of the company requires an annual operating capital of $\$ 452,210.94$ USD. [11]. The provision of loans by microfinance banks, NGOs and agricultural institutions to private sector participants that is willing to operate as waste managers with long term payback period will help encourage their participation in waste management since the process is capital intensive. Also, the establishment of processing industries for recycling of solid waste within the town will encourage private sector participation as this will serve as a source of income.

Table1: An inventory for a private sector participant in solid waste management (BESESA,2005)

\begin{tabular}{lllll}
\hline Description & Qty. & $\begin{array}{l}\text { Unit } \\
\text { Cost } \\
\mathbf{\$}\end{array}$ & $\begin{array}{l}\text { Duration } \\
\text { (Months) }\end{array}$ & $\begin{array}{l}\text { Amount } \\
\mathbf{\$}\end{array}$ \\
\hline Staff (senior) & 5 & 93.75 & 12 & 3,750 \\
Staff (junior) & 5 & 62.50 & 12 & 2,625 \\
Cargo Rare Loading & 2 & 218,75 & - & 437,500 \\
Trucks & 10 & 43.750 & - & 437.50 \\
Wheel Barrows & 15 & 9.375 & - & 140.625 \\
Shovels & 15 & 0.313 & - & 4.695 \\
Brooms & 15 & 3.125 & - & 46.875 \\
Rakes & 15 & 1.250 & - & 18.75 \\
Hand gloves & - & - & - & 12,500 \\
Maintenance/Repairs & 30 & 9.375 & - & 281.250 \\
Apron & 30 & 15,625 & - & 468.75 \\
Safety Kits & 50 & 1.250 & - & 62.50 \\
Nose Mask & & & & $\mathbf{\$ 4 5 2 , 2 1 0 . 9 4}$ \\
Total: & & & & \\
\hline
\end{tabular}

Previous studies have shown that, those involved in the process are not really comfortable as the job is not lucrative as expected but rather very tedious [5]. Most of the individual waste collectors have their primary aim of either reuse or recycling of the collected wastes into other semifinished or finished materials in order to maximize their profit. These workers make use of push carts, wheelies, wheel barrows, sacks, baskets, etc. for the collection exercise.

The data provided by this study will avail future private operators, the information they need to make an informed decision to partner with government in managing waste in the study area. The findings from the research will provide necessary statistics for government to make legislations that will entrench waste management consciousness in the governed.

\section{Methodology}

\subsection{Description of Study Area}

Makurdi is located in the Benue valley. It is the capital of Benue State and also a local government council 
headquarters. It has a surface area of about 16 kilometers radius and is called greater Makurdi, as provided in the greater Makurdi edit of 1984. Makurdi lies across both banks of the River Benue surrounded by Lafia , Keana and Doma Local government areas of Nasarawa State (North), Guma and Tarkaa local government areas (East), Gwer-East (South) and Gwer-West (West). Makurdi is cosmopolitan in nature with people of diverse cultural backgrounds. Some of the minor tribes within the metropolis include Ibo, Hausa, Etulo, Igala, Alago, Jukum, Kabawa, Igede, with Idoma trailing behind Tiv as the major indigenous tribes. The Tiv tribe accounts for over $90 \%$ of the total population.

It experiences a typical tropical climate with two distinct seasons; wet or rainy and the dry seasons, with annual rainfall of $150 \mathrm{~mm}$. The dry season begins in November and ends in March with corresponding harmattan, cold and chilly weather from December to early February, hot

weather and high temperature between early February and April (Makurdi, 2002 . $2^{\text {nd }}$ all local government agricultural development trade fair).

For the purpose of this study, Makurdi metropolis is grouped into urban, semi urban and rural centers, namely;

Urban center; (Wadata, High level, Wurukum, Mordern market and Gboko road)

Semi Urban center; (Kanshio, Apir and Nakaroad)

Rural center; (Agan, Adeke and Fiidi)

\subsection{Population projection for Makurdi}

Based on the 1991 census figure [12], Makurdi local government area had a total population of about 235,599, with an annual growth rate of $2.8 \%$. Therefore, the projected figure for 2013 is given as;

$$
2013 \text { total population }=\left\lfloor\frac{2.8}{100} \times 235,599\right\rfloor \times 22 \text { years }+235,599=380,723
$$

The urban center and the semi urban center population was 151,515 with a growth rate of $2.8 \%$. This can be projected for 2013 as follows;

$$
2013 \text { Total population }=\left[\left(\frac{2.8}{100}\right) \times 151515\right] \times 22 \text { years }+151,515=
$$

This stands as the present estimated population of urban and semi urban dwellers.

\section{Research Design}

The study is a survey dealing with the collection of information on solid waste generators and collectors. Questionnaires were administrated to both the generators and collectors within the urban and semi urban areas of Makurdi metropolis. Emphasis was laid mostly on the urban and semi urban areas as impact of waste management practices in the rural areas is almost negligible. Within the urban areas, 3419 units of households and 3063 small scale business premises as well as large scale industries were sampled for the administration of questionnaires. Notwithstanding the poor responses from rural areas, questionnaires were administered to some of the residents and individuals involved in waste collection for reuse or recycling as they move round to handpick the deposited solid waste using sacks, cartoons etc Structured questionnaires were in two categories of solid waste generators and collectors.

\subsection{Method of Data Collection}

300 structured questionnaires were designed for solid waste generators, and were distributed to residents with more emphasis laid on the residents at the beginnings, midway and endings of every street to the right hand side and left hand sides respectively. Business or industrial premises situated on both sides of road/street junctions were also sampled in the cause of the study. Of the 300 questionnaires, 150 were administered to household units,
130 to business premises and 20 to industries. As detailed below; 90 questionnaires were distributed to High level, 60 to Wurukum, 40 to Modern Market, 40 to Gboko Road, 20 to Kanshio-Apir, 15 to Naka Road, 10 to Agan, 10 to Adeke and 15 to Fiidi areas.

On the other hand, structured questionnaires designed for solid waste collectors were distributed to five registered private sector (individuals) companies involved in solid waste collection processes.

\section{Results and Discussions}

The results obtained from both the waste generator and collectors are presented in tables and figures below.

Table2: frequency private sector emptying their waste container

\begin{tabular}{lll}
\hline Period & Frequency Distribution & \% Distribution \\
\hline Daily & 64 & $21.33 \%$ \\
$1-5$ days & 14 & $4.66 \%$ \\
Weekly & 77 & $25.67 \%$ \\
$2-3$ Weeks & 31 & $10.33 \%$ \\
Monthly & 102 & $34.00 \%$ \\
& 12 & $4.00 \%$ \\
One Month & & $\mathbf{1 0 0 \%}$ \\
\hline
\end{tabular}




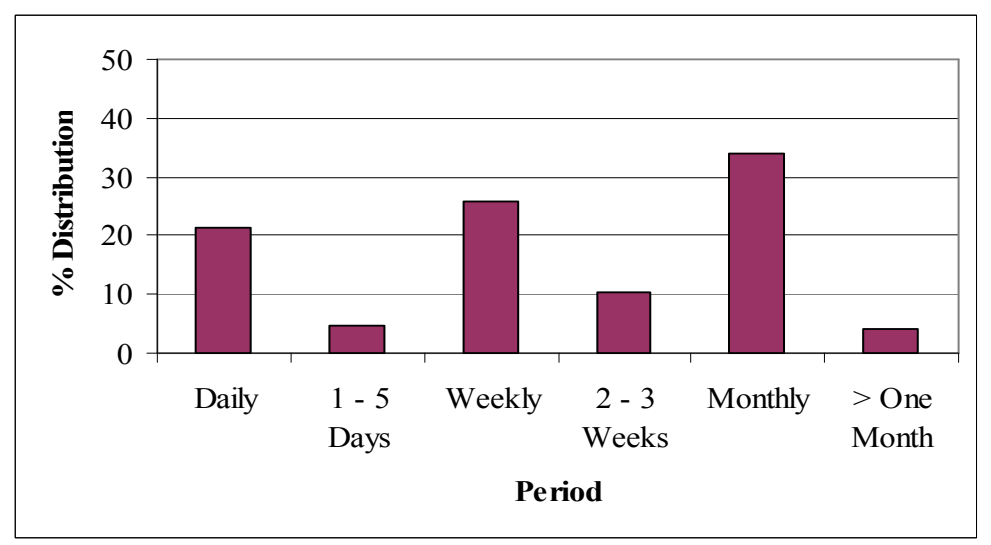

Figure1: Percentage distribution of how frequent household/Industries empty their containers.

Table 2 and Figure 2 addresses research question one. This sought to find out how frequent households/industries empty their waste containers. It indicates that $34 \%$ of the respondents dispose off their waste monthly, $26 \%$ weekly, $21 \%$ daily, $10 \% 2-3$ weeks, $5 \% 1-5$ days and $4 \%$ greater than one month period. The higher percentage distribution of monthly disposal of waste is attributed to the enforcement of the compulsory monthly waste management exercise (Monthly sanitation) by the state government; the weekly cleaning is carried out by staff and students that are engaged during the working days.
Table3: The Containers/Machineries employed in the waste collection process

\begin{tabular}{lll}
\hline Equipment/Machines & $\begin{array}{l}\text { Frequency } \\
\text { Distribution }\end{array}$ & \% Distribution \\
\hline Bucket/Cartons & 53 & $53.00 \%$ \\
Wheel Barrow/Wheelie Bin & 37 & $37.00 \%$ \\
Push Cart & 8 & $8.00 \%$ \\
Trucks & 2 & $2.00 \%$ \\
Total: & $\mathbf{1 0 0}$ & $\mathbf{1 0 0 \%}$ \\
\hline
\end{tabular}

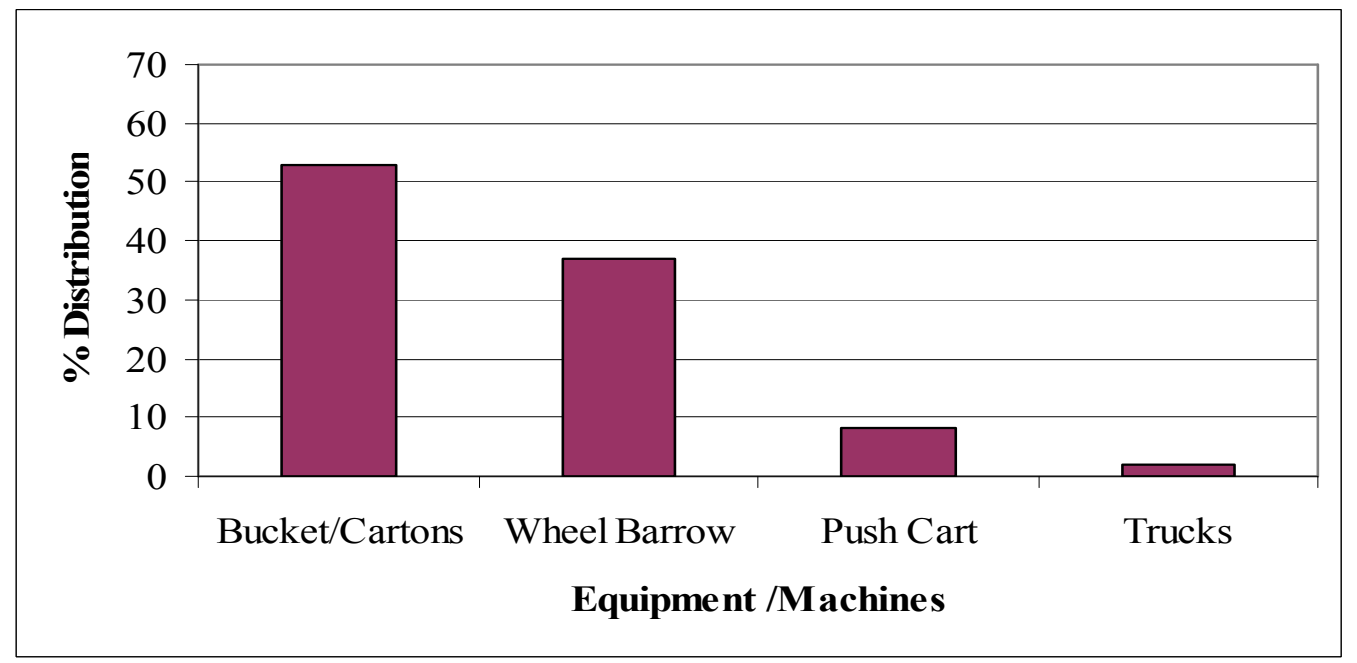

Figure3: Percentage distribution of Equipment/Machines employed for waste collection process.

Table 3 and Figure 3 show the frequency distribution of equipment/machines used for Waste collection processes. The table indicates that, the highest fraction of respondents (53\%) collect waste by the use of bucket/cartons, $37 \%$ collect by wheel barrows/wheelie bins, $8 \%$ push cart and only $2 \%$ use trucks. The use of trucks for waste collection is common amongst the industries as they generate huge mass of waste. Residents prefer to collect waste with the aid of plastic bucket or paper cartons. The push cart at most is used by large compounds and recycling or reuse persons.

\section{Profitability Analysis}

The state government has being budgeting huge amount of money for waste management project, it has become imperative that the project is not sustainable without private sector participation. The state government now came out with a tariff that will encourage private sectors to invest as shown in Table 4 [11]. This indicates that, the project is capital intensive for the private sector to venture into for 
income generation [13], except the current unwillingness to pay by waste generators is reduced by education and enactment of law by the sanitation authority and sustained enforcement to compel the generators of waste to pay for the waste they generate.

Table 4: Tariffs for Waste Management by the Benue State Government. (BESESA,2005)

\begin{tabular}{|c|c|c|c|c|}
\hline $\mathbf{S} / \mathbf{N}$ & Description & $\begin{array}{l}\text { Number of } \\
\text { Tariff Units }\end{array}$ & $\begin{array}{c}\text { Tariffs/month } \\
\$\end{array}$ & $\begin{array}{c}\text { Total Cost/ } \\
\text { Month \$ }\end{array}$ \\
\hline \multirow{2}{*}{\multicolumn{5}{|c|}{ 1. Residence Buildings }} \\
\hline & & & & \\
\hline & $\leq 3$ Bedrooms & 300,000 & 2.188 & 656,400 \\
\hline & $\geq 3$ Bedroom & 250,000 & 3.130 & 782,500 \\
\hline & Huts & & & \\
\hline & Residential Compounds & & & \\
\hline & $\leq 10 \mathrm{~h} / \mathrm{hds}$ & 50,000 & 3.130 & 156,500 \\
\hline & $\geq 10 \mathrm{~h} / \mathrm{hds}$ & 30,000 & 6.250 & 187,500 \\
\hline \multicolumn{5}{|c|}{ 2. Commercial Houses } \\
\hline & $\begin{array}{l}\text { K1osk } \\
\text { Container }\end{array}$ & $\begin{array}{c}10,000 \\
1000\end{array}$ & 2.50 & $\begin{array}{c}12,500 \\
2,500\end{array}$ \\
\hline & Supermarket & & & \\
\hline & Small & 3,000 & 3.130 & 9,390 \\
\hline & Large & 200 & 625 & 1,250 \\
\hline & Internet service providers & 30 & 12.50 & 375 \\
\hline & Beer Palour & 4,500 & 2.50 & 11,250 \\
\hline & Salon & 4,000 & 3.130 & 12,250 \\
\hline & Food vendor & 4,800 & 188 & $9,024,000$ \\
\hline & Food canteen & 3,000 & 188 & 564,000 \\
\hline & Hotel of $1-10$ rooms & 500 & 12.50 & 6,250 \\
\hline & Hotel of $10-20$ rooms & 250 & 31.25 & $7,812.50$ \\
\hline & Hotel of 20-30 rooms & 20 & 62.50 & 1,250 \\
\hline & Filling station & 450 & 62.50 & 28,125 \\
\hline & Computer Business Centers & 2,000 & 3.130 & 6,260 \\
\hline & Telecom Service Centers & 4 & 25 & 100 \\
\hline & Abattoirs & 3 & 31.25 & 93.75 \\
\hline & Mechanic Workshops & 450 & 188 & 846 \\
\hline \multicolumn{5}{|c|}{ 3. Hospital/Clinic } \\
\hline & $10-20$ beds & 30 & 62.50 & 1,875 \\
\hline & $>20$ beds & 10 & 93.75 & 937.50 \\
\hline & Maternity home & 15 & 18.75 & 281.25 \\
\hline & Pharmacy & 100 & 1.25 & 125 \\
\hline & Medicine stores & 250 & 3.130 & 782.50 \\
\hline & Federal Medical Center & 1 & 187.50 & 187.50 \\
\hline \multicolumn{5}{|c|}{ 4. School/College } \\
\hline & Primary without Residential & 1,500 & 31.25 & 46,875 \\
\hline & Secondary without Residential & 800 & 43.75 & 35,000 \\
\hline & Secondary with residential & 10 & 93.75 & 937.50 \\
\hline & Tertiary institutions & 6 & $187.50-625$ & 3,750 \\
\hline \multicolumn{5}{|c|}{ 5. Places of Worship } \\
\hline & $<500$ worshippers & 1500 & 3.130 & 4,695 \\
\hline & $>500$ worshippers & 120 & 6.25 & 750 \\
\hline \multicolumn{5}{|c|}{ 6. Others } \\
\hline & Local Government Secretariat & 1 & 93.750 & 93.75 \\
\hline & Govt. Mins./Parast./Dept. & 20 & 31.250 & 625.00 \\
\hline & Government House & 1 & 187.50 & 187.50 \\
\hline & Benue State House of Assembly & 1 & 187.50 & 187.50 \\
\hline & Benue Judiciary & 4 & 187.50 & 750.00 \\
\hline & Block industries & 40 & 3.130 & 125.20 \\
\hline & Ware Houses & 20 & 6.25 & 125.00 \\
\hline & Parks/Resorts & 25 & 12.50 & 312.50 \\
\hline & Printing Press & 35 & 3.130109 .55 & \\
\hline & Timber Dealers & 20 & 25.00 & 500.00 \\
\hline & Furniture makers & 70 & 12.50 & 875.00 \\
\hline & Total Cost/ Month: & & & \$ $1,997,646.88$ \\
\hline & Total Cost per Annum: & & & $\$ 23,971,762.50$ \\
\hline
\end{tabular}


Tables 1 indicated that, for each of the five (5) registered service providers in Makurdi, a capital of \$452,210.94 per annum is required for the investment. From Table 4. $\$ 23,971,762.50$ is expected from the business at the end of the year of which five of the service providers can get about $\$ 4,794,352.50$ each.

For a private company that ventures into the business by collecting loan of $\$ 452,210.94$ at $21 \%$ interest for a period of 5 years from any commercial institution (example banks) as capital will experience the following interest;

Using, Simple Interest $=\frac{\text { principal } \times \text { Rate } \times \text { Time }}{100}=$ $\frac{452,210.94 \times 21 \times 5}{100}=\$ 474,821.490$

This implies that, a year requires: $\frac{474,821.490}{5}=$ $\$ 94,964.30$

While a month requires: $=\frac{94,964.30}{12}=$

$\$ 7,913.69$

This can be realizable through enactment/sustained enforcement of sanitation laws to compel the waste generators to pay for the waste they generate.

Three models (NPV, PI and ROI) were used to estimate the viability of the project for one year based on the follow results and findings from the study.

$$
\text { Amount realizable per year }=\$ 4,794.35: 400
$$

Amount for servicing of loan $=\$ 94,964.29: 50$

Amount for running cost $=\$ 452,210.94: 00$

Net Cash at Hand = Amount Realizable - (Amount for servicing loan + Amount for Running cost)

Net Cash at Hand $\quad=\$ 481,852.50-(\$ 94,964.30+$ $\$ 452,210.94)$

$=\$ 4,794,352.50-\$ 54,712.73$

$=\$ 4,247,177.27 * *$

- Net Present Value (NPV) for a year $=A_{0}+$ $\sum_{t=1}^{n} \frac{f_{t}}{\left(1+k+p_{t}\right)^{t}}$

Where; $A_{0}$ is initial cash investment $=$ N72, 353,750:00 (negative)

$\mathrm{f}_{\mathrm{t}}$ is net cash flow in period $(\mathrm{t})=\$ 4,247,177.27: 50$

$\mathrm{k}$ is required rate of return $=21 \%$

$\mathrm{n}$ is number of years $=1$

$\mathrm{p}_{\mathrm{t}}$ is inflation rate $=9.5 \%$ for Nigeria( FBS, 2013), therefore;

$\mathrm{NPV}=-\$ 452,210.94: 00+\$ 4,247,177.27: 00 /(1+0.21$ $+0.095)^{1}$

$=\$ 2,802,331.03: 00$

- $\quad$ Profitability Index (PI)

$=P$ Present values of all expected cash inflows $=\frac{\$ 2,802,331: 00}{\$ 452,210.94: 00}=6.2$

- $\quad$ Return on investment (ROI) index $=\frac{\sum R_{i} /(1+r)^{i}}{\sum I_{i} /(1+r)^{i}}$

Where;

$i$ is number of years of investment $=1$ year

$\mathrm{R}_{\mathrm{i}}$ is net returns expected from the project in the $\mathrm{i}$-th year $=\$ 4,247,177.27: 50$
$\mathrm{I}_{\mathrm{i}}$ is investment expected to be made in the $\mathrm{i}$-th year

$=\$ 452,210.94: 00$

$\mathrm{r}$ is interest rate $=0.21$. Therefore;

ROI index $=\frac{\$ 4,247,177.27 / 1+0.21}{\$ 452,210.94 / 1+0.21}$

$=9.4$

* This is the total amount (gross income) that can be realized by private sector participants (say five) in Makurdi metropolis, if all things are done rightly.

** Net income for one company operating a waste cleaning outfit in Makurdi metropolis under strict supervision of the environmental sanitation authorities.

\section{Conclusion and Recommendations}

Solid waste management operations are capital intensive as they require the use of equipment and machines such as wheel barrows, wheelie, push carts, trucks and tractors for hauling of waste. This research reveals that, there is low participation of the private sector, in solid waste management within Makurdi metropolis. Many residents are reluctant to employ the services of waste management workers since they refer to waste collection practice as personal responsibility. It also reveals that, solid waste management practice as a business in Makurdi metropolis is a viable one for private sector involvement. The research also suggested profitable measures that can benefit both the government and private sector in the solid waste management process.

From the data gathered which precedes a cost - benefit analysis and a statistical tool of simple interest, the following recommendations based on findings are quite pertinent;

i. The lackadaisical attitude of residents towards waste management issues call for the enactment and sustained enforcement of environmental sanitation laws that compels the waste generators to pay for their wastes, failure of which should attract enforceable fine or penalty.

ii. The provision of loans by microfinance banks, commercial banks, NGOs and agricultural institutions to private waste management companies, willing to operate as waste managers with long term payback period will help encourage their participation in waste management, since the process is capital intensive.

iii. Creation of awareness on the effects of waste in our environment by health workers, NGOs and government organization through campaigns in churches, mosques, town union etc will help educate residents on the dangers of waste and why its management must by practiced.

iv. The establishment of processing industries for reuse and recycling of solid waste within the town will encourage private sector participation as this will serve as a source of income. 
v. The large waste volumes in Makurdi could provide a source of fuel to which the urban poor can have access. That is, urban waste-to-energy considerations need to be explored. The production of energy from waste should form part of a wider poverty alleviation process.

vi. More research should be done in this area to determine the current per-capital waste generation of residents vis-avis the collection efficiencies of the suggested 5 private companies in this work.

vii. Government should in the mean time, create more "sacrifice areas" for dumping and incineration of the waste by the private companies as this will enhance collection efficiencies. They should also play a supervisory role in the waste management process in order to determine redundancies of registered companies as well identify and correct bottlenecks in the process.

\section{References}

[1] Green (2008) http://myerowaste.com/articles/general/whatis-waste/ (Untitled)

[2] World Bank (1999) what a waste: solid waste management in Asia Urban Development Sector Unit East Asia and Pacific region. May.

[3] Wilson, D., Whiteman, A., Tormin, A. (2001). Strategic planning guide for municipal solid waste management. Washington, DC: World Bank. http://www.worldbank.org/urban/solid_wm/erm/start_up.pdf

[4] International Solid Waste Association \& United Nations Environment Programme (ISWA \& UNEP) (2002). Waste Management, 'Industry as a partner for sustainable development'. ISBN: 92-807-2194-2, 2002.
[5] Ahmed A.S and Ahmed M.A (2004) Partnerships for solid waste management in developing countries: Linking theories to realities Habitat International, 28 (3), pp. 467 479

[6] Rahman, M Salequzzeman, Md. Buhar, M, Uddin, N, Islam, A, al Huran, A.Y. (2005). People's Perception of the Existing Solid Waste Management of Khulna City Corporation (KCC) Area: A Case Study of Participatory Management. National Workshop for REGA and CDM Awareness Building \& Motivation sponsored by the ADB PREGA Project; Khulna.

[7] Tennessee Solid Waste Education Project (2008), www. Tennessee.org. (Date visited: $15^{\text {th }}$ October, 2009)

[8] Federal Ministry of Environment (2005), National Environmental Sanitation Policy. Federal Ministry of environment, Jan. pp. 8

[9] Sha'Ato, R., Aboho, S.Y., Oketunde, F.O (2003) Survey of the Waste Situation in Makurdi Urban Area. SLGP Consultants Report No. 89 DFID-SLGP Benue.

[10] First Agro Industrial Promoters Limited (FAIPL) (2002). Technical and Economic Feasibility Study Report on Benue State Domestic Refuse Sorting, Composting and landfilling Project. Lagos FAIPL May.

[11] Benue State Environmental Sanitation Authority Law (2005), Vol. 30. Government Printer, Makurdi.

[12] National Population Commission, NPC, (1991), Population Census of the Federal Republic of Nigeria. Analytical Report at the National Level. National Population Commission.

[13] Yeny D, and Yulinah T 2012 SolidWaste Management in Asian Developing Countries: Challenges and Opportunities J. Appl. Environ. Biol. Sci., 2(7)329-335, 2012 (C) 2012, TextRoad Publication ISSN: 2090-4274 Journal of Applied Environmental and Biological Sciences www.textroad.com . 